\title{
Using Demonstration in Teaching Writing through Procedure Text for SMA Students
}

\author{
Silfi Sanda \\ SMAN 4. Baturaja OKU Palembang
}

\begin{abstract}
This paper is mainly about using demonstration for teaching writing by using procedure text in relation to local culture in English language teaching. Recipe of local food is one of the procedure texts that can be applied in teaching writing. The local culture exposed in the text is the local food of Palembang, Pindang, in term of how to make it. How to make Pindang consists of a series of steps which shows how to achieve some goals, called procedure text. In curriculum of SMA, procedure taught as one kind of text materials in English teaching learning process at school. The technique employed for comprehending and appreciating this text is demonstration teaching technique and presenting technique designed especially for motivating students' focus on the text, technique activities for developing students' writing ability.
\end{abstract}

Key words: Demonstration, Local Food, and Procedure Text.

\section{A. Introduction}

In government curriculum, school should have their own curriculum which is called KTSP (Kurikulum Tingkat Satuan Pendidikan) of themselves. KTSP could be differ one and the other districts. KTSP usually made by the school curriculum team based on the students' need and local situation. KTSP includes the school interest and facilities related to their sorrounding.

Writing is a complex process that allows writers to explore thoughts and ideas, and make them visible and concrete. Writing encourages thinking and learning for it motivates communication and makes thought available for reflection. When thought is written down, ideas can be examined, reconsidered, added to, rearranged, and changed. Writing is most likely to encourage thinking 
and learning when students view writing as a process. By recognizing that writing is a recursive process, and that every writer uses the process in a different way, students experience less pressure to "get it right the first time" and are more willing to experiment, explore, revise, and edit. Yet, novice writers need to practice "writing" or exercises that involve copying or reproduction of learned material in order to learn the conventions of spelling, punctuation, grammatical agreement, and the like.

Teaching English writing is basically not easy. It is understandable because there are some problems faced by the English teachers. First, the students are generally confused by what they want to write. They have no idea what to write. Worst, a few minutes before the class ends, they just write one to three sentences. Second, the students do not always hear English in their daily life. They just hear English at school. So it is very difficult for them to master all the English rules and a lot of vocabulary items taught. Third, the students have different reasons to learn English. They learn English because it is a compulsory subject provided by the curriculum. They only want to pass the examination. Therefore, the students do not always have motivation to reach the optimal target. Students' understanding and ability in writing procedure text is still low. They tend to imitate the sample that is given by the teacher without considering the difference of the text. It is caused by the use of inappropriate technique in teaching writing especially in procedure text, so in this time the writer use demonstration as a medium in teaching writing especially in procedure texts.

\section{B. General Concept of Writing}

\section{B.1. Definition of Writing}

Definition of writing is conveyed differently by Harmer (2007:113). He says that writing is various stages (planning, drafting,editing, etc) that writers go through in a variety of sequences in order to compose written text.

The definitions above imply that writing is an activity of creating and composing written text.

\section{B.2. The Writing Process}

Richards (2002: 14) states that "leaming to write involves imitating and manipulating models provided by the teacher and is closely linked to learning 
grammar". It means that the students need to know the sequence of activities involved in a writing lesson. They are as stated below:

1) Familiarization

2) Controlled Writing

3) Free Writing

4) Guided Writing

\section{B. 3. Procedure Text}

Procedure, according to Anderson and Anderson (1997: 50) means "a piece of text that gives us instructions for doing something". The purpose of a procedure text type is to explain how something can be done such as directions, recipes, instruction manual, and itineraries. Anderson and Anderson (1997; 52-55) state that the generic structure of a procedure text contains:

1) An introductory statement that gives the aim or goal This may be the title of the text or an introductory paragraph

2) Alist of the materials that will be needed to complete procedure

a. This may be a list or a paragraph

b. This step may be left out in some procedures

3) A sequence of steps in the order they need to be done

a. Numbers can be used to show first, second, third, and so on

b. The order is usually important; such words as now, next, and after this can be used

c. Usually the steps begin with a command such as add, stir, or push

While the linguistic features of a procedure text are:

a. The use of technical language

b. Sentences that begin with verbs and are stated as commands

c. The use of time words or numbers that tell the order for doing the procedure

d. The use of adverbs to tell how the action should be done (Anderson and Anderson, 1997: 52).

B. 4. Teaching Writing Procedure Text

The aim of teaching writing is to help students deal with writing in their real life. Yet there is a huge variety of types of writing in our real life. It is suggested 
that we choose some of the writing situations that largely feature the students'daily activities. such as how to send an e-mail, how to sharpen a pencil, how to make a pencil box, how to cook something etc.

Hyland (2004: 12) explains that to create a well-formed and effective text, students should know how texts are organized, and the lexicogrammatical patterns used. It involves the social purposes of the text type, the kinds of situation, who the probable audience is, what readers are likely to know, and the roles and relationships of text users, the types of textual variation, and how the genre is related to the target context.

Furthermore, Hyland (2004: 54) states that "Genres are specific to particular cultures and communities...". It means that if the students create texts in English, they should know the rhetorical stages used in English. The cycle of teaching and learning activities in genre approach consists of a number of stages. Hammond et al. (1992: 17) states that "the classroom program is based on four stages in a teaching-learning cycle: Building Knowledge of the Field, Modeling, Joint Construction, and Independent Construction of the Text".

There are two major categories of genres. They are story genres and factual genres. Story genres divided into six subcategories, such as narrative, recount, anecdote, exemplum, repartee, and dialogue. Factual genres divided into eight subcategories, such as description, report, biography, procedure, exposition, explanation, discussion, and exploration. Instructions include procedure in factual genres (cf. Martin 1992: 546-573, Larson 1984: 365-388, Callaghan \& Rothery, 1988: $33-90$ and Tou 1997:387-389). The principal type is set out in Table 1.

Table 1: Genre (Callaghan \& Rothery, 1988: 53-90)

\begin{tabular}{|c|c|c|c|}
\hline $\begin{array}{l}\text { Genre } \\
\text { type }\end{array}$ & Function & $\begin{array}{l}\text { Generic (Schematic) } \\
\text { Structure }\end{array}$ & Language features \\
\hline 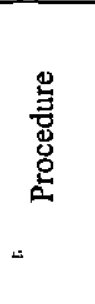 & $\begin{array}{l}\text { Factual text } \\
\text { designed to } \\
\text { describe how } \\
\text { something is } \\
\text { accomplished } \\
\text { through a sequence } \\
\text { of actions or steps }\end{array}$ & $\begin{array}{l}\text { Goal } \\
\text { Steps 1-n (i.e. } \\
\text { Goal followed by } \\
\text { a series of steps } \\
\text { oriented to } \\
\text { achieving the } \\
\text { goal) }\end{array}$ & $\begin{array}{l}\text { - Focus on generalised human agents } \\
\text { - Focus on generic participants } \\
\text { - Use of simple present tense (plus } \\
\text { sometimes imperatives) } \\
\text { - Use of mainly temporal conjunctive } \\
\text { relations } \\
\text { - Use of mainly material (action) } \\
\text { processes }\end{array}$ \\
\hline
\end{tabular}


In curriculum of SMP and SMA, procedure taught as one kinds of text materials in English teaching learning process at school.

\section{General Knowledge of Demonstration}

The definition of demonstration according to some experts are:

1) Demonstration is an instance of somebody showing and explaining how something works or is done. (Hornby, 1995:310)

2) Joesoef Djajasastra (1982: 93) states that demonstration is a way to represent the subject by showing the objects directly or a way to do something

3) Demonstration means the simple act of pointing to an object, area, or place like the sun, the moon. (Wikipedia: 2009).

From the definitions above, we come to the conclusion that demonstration is a medium used in the teaching-leaming processes to show something by using objects directly.

The functions of media in general, demonstration in particular, and their contributions to language learning according to De Porter and Hernacki (2004: 13) are "to create an optimal environment, either physical or mental". Furthermore, Sukartiwi, cited in Depdiknas (2004: 13) explains that demonstration gives some advantages in the teaching-learning processes: to improve students' motivation, to avoid students' boredom learning in the classroom, to ensure that the teachinglearning processes run systematically, to make it easier for students to understand the teacher's instructions, to build the students' knowledge of the expected teaching in the context.

\section{Teaching Writing using Demonstration}

Much of what we say in daily conversation in any language is prompted by what we see or have seen. Therefore, Haycraft (1978: 97) proposes that "in a language learning situation a teacher should give much practice in reacting in English to objects, or things". Objects or things allow us to explain a word or concept in a simple way. As has been mentioned before, time can be saved by using objects or things because showing the objects directly is a more rapid process than speaking or explaining. We choose demonstration as a medium for teachinglearning processes in the teaching of writing procedure text. 
How to demonstrate something can be shown to the students with the sequence of steps done by the teacher while writing the text of the demonstration model on the blackboard. The students, in this case, did not only pay attention to teacher's demonstration, but also guess the answer to teacher's questions of demonstration. So here, the teacher created the teaching-learning process to become interactive learning. By applying the demonstration, teaching writing of procedure text became more understandable. Besides, students became interested in joining the writing class, could break their boredom, and improve their knowledge in writing skill.

\section{Lesson Plan .}

School

Subject

Class

Meeting

Allocation Time

StandardizedCom

\section{Lesson Plan}

: Senior High School

: English

$: \mathrm{X}$

:-

:45 minutes

Mengungkapkan makna dalam teks tulis fungsional pendek dan teks monolog/esei tulis sederhana secara akurat, lancar, dan berterima berbentuk recount, narrative dan procedure dalam konteks kehidupan sehari-hari dan mengakses ilmu pengetahuan populer.

Basic Competence : Mengungkapkan makna dan langkah-langkah retorika secara akurat, lancar dan berterima menggunakan ragam bahasa tulis dalam teks berbentuk recount, narrative dan procedure.

Indicators : To be given a procedure text, students are able to demonstrate and write procedure text.

I. Teaching Material

II. Teaching Approach.

III. Teaching and Learning Steps
: How to Make Pindang Meranjat

: Demonstration

a. FreeActivities

Teacher introduces Pindang as one oflocal food from South Sumatra. 
b. WhilstActivities

Students listen the text of How to make Pindang.

Teacher demonstrates How to make Pindang.

\section{Pindang MERANJAT}

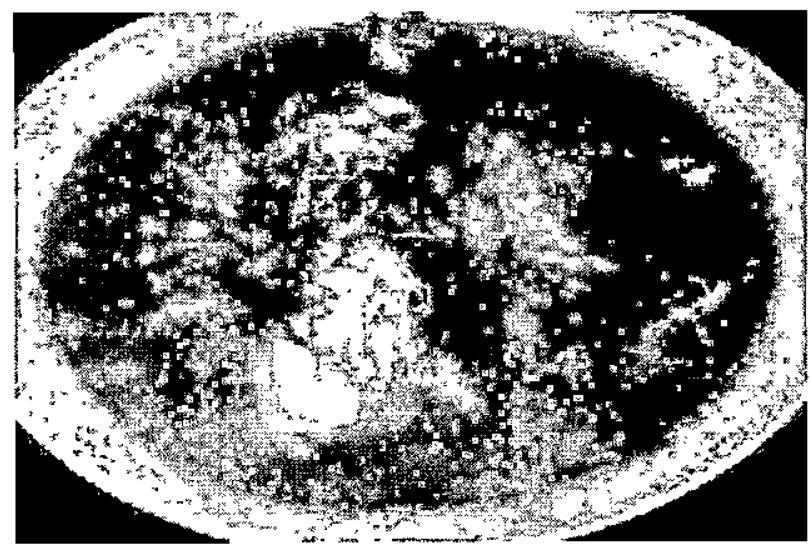

\section{Ingredients:}

Fish Gabus $250 \mathrm{gr}$

$600 \mathrm{ml}$ of water

$1 / 4$ pineapple fruit, meat only waiting

Thumb 1 Javanese acid

3 stalks basil leaves

1 leek, cut length

1 teaspoon sugar

salt \& flavor

Oil for frying

\section{Spices are blended:}

5 red chilies

4 spring onions

Tomatoes 1

$1 / 2$ tsp roasted shrimp paste 


\section{Cooking:}

- Marinate the fish with lemon and salt water for $1 / 2$ hour, then fried.

- Mix the spices are blended with water, which had been cut pineapple dice and Java acids.

- After boiling input fish, basil, scallions, sugar and salt flavor.

- After basil and wilted leeks lift, serve with fresh basil and a sprinkling of fried onions.

\section{Note:}

- Fish should use the river fish (cork and catfish). Fish should be fried first or directly incorporated into the sauce without frying first, depending on taste.

- If you use traditional marine fish, we suggest you choose white meat fish such as snapper, and fried fish first, so no fishy taste.

c. PostActivities

$\checkmark$ Students write the text of How to make Pindang.

$\checkmark$ Reinforcement

IV. Teaching Aids

V.Place of Teaching and Learning Activities : Classroom

VI. Evaluation
: Power Point, Computer

:Written Test
Palembang, December 19, 2009

English Teacher,

Head Master of SMA ... 


\section{E. Conclusion}

Demonstration can be applied in the teaching writing of procedure text. How to demonstrate something can be shown to the students with the sequence of steps done by the teacher while writing the text of the demonstration model on the blackboard. The students, in this case, do not only pay attention to teacher's demonstration, but also guess the answer to teacher's questions of demonstration. So here, the teacher creates the teaching-learning process to become interactive learning. By applying the demonstration, teaching writing of procedure text became more understandable. Besides, students will interested and improve their knowledge in writing skill.

\section{Bibliography}

Anderson, Mark and Anderson, Kathy. 1997. Text Type in English. South Yarra: Macmillan Educaton Australia PTYLTD.

Brown, H. Douglas. 2004. Language Assessment Principles and Classroom Practices. New York: Pearson Education, Inc.

Departemen Pendidikan Nasional. 2004. Media Pembelajaran Bahasa Inggris Bahan Pelatihan Terintegrasi Berbasis Kompetensi Guru SMA Bahasa Inggris. Jakarta: Depdiknas.

Depdiknas. 2005. Kurikulum Bahasa Inggris 2004 untuk SMA. Jakarta: Departemen PendidikanNasional.

Djamrah Bahri Syaiful and Zain Aswan. 2003. Strategi Belajar Mengajar. Jakarta: Rineka Cipta.

Eggins, S. 1994. An Introduction to Systemic Functional Grammar. London: Pinter Publisher.

Feez, S. 1998. Text-Based Syllabus Design. Sydney: Macquarie University.

Finocchiaro, M. Bonomo. 1973. The Foreign Language Learners: A Guide for Teachers. NY: New York, Regents Publishing Company, Inc.

Gerlach, Vernon S, Ely D.P. 1980. Teaching and Media: A Systematic Approach. New Jersey, NJ: Prentice Hall. 
Gerot, Linda and Wignell. 1995. Making Sense of Functional Grammar. Sydney: Gerd StablerAntipodian Educational Enterprises (AEE).

Halliday, M.A.K. 1994. An Introduction to Functional Grammar. $2^{\text {nd }}$ ed. Routledge: Chapman and Hall; Inc.

Hammond et al. 1992. English for social purposes: A Handbook for Teachers of Adult Literacy. Australia: Macquire University.

Harmer, Jeremy. 2004. How to Teach Writing. Essex: Pearson Education Limited.

Haycraft, J. 1983. An Introduction to English Language Teaching. Great Britain: Longman Group.

Hyland, Ken. 2004. Genre and Second Language Writing. USA: The University of Michigan Press.

Porter De Bobbi and Hernacki Mike.2004. Quantum Teaching. Bandung: Kaifa.

Satuan Pendidikan (KTSP). Jakarta: Departemen Pendidikan Nasional.

Richards, Jack C. 30 Years of TEFL/TESL: A Personal Reflection. SEAMEO Regional Language Centre Singapore.

Wright, Andrew. 1983. Visual Material for the Language Teachers. London: Longman. http://en.wikipedia.org/wiki/Syllabus. 